\title{
Prediction of Pre-Eclampsia in Second Trimester by Estimating the Spot Urinary Protein Creatinine Ratio
}

\author{
Priyanka Jayaraman ${ }^{1}$, Sheila Kamalasan Pillai ${ }^{2}$ \\ 1,2 Department of Obstetrics \& Gynaecology, Sri Ramachandra Institute of Higher Education and Research, \\ Porur, Chennai, Tami Nadu, India.
}

ABSTRACT

\section{BACKGROUND}

Pre-eclampsia is unique to pregnancy and is characterized by multisystem involvement and glomerular endotheliosis. There is increased glomerular basement membrane permeability to proteins leading to significant proteinuria. This study has been done to evaluate the spot urinary protein creatinine ratio in pregnant women from 13 to 20 weeks of gestation and assess its usefulness in predicting their risk of developing pre-eclampsia subsequently.

\section{METHODS}

This is a prospective observational study conducted in the Department of Obstetrics and Gynaecology at Sri Ramachandra Medical College and Research Institute, Chennai from November 2017 to October 2019. The patients were followed up till delivery and in the early postpartum period for the development of pre-eclampsia and any maternal complications. After delivery, new-born babies were followed up till early neonatal period for adverse neonatal outcomes.

\section{RESULTS}

In this study, $6.1 \%$ of patients (29 cases) had Protein Creatinine Ratio (PCR) more than or equal to 0.3 . Among these 29 cases 27 cases (93.1\%) developed preeclampsia. 6 (22.2\%) cases had severe preeclampsia and $21(77.8 \%)$ cases had mild preeclampsia. Occurrence of headache, blurring of vision and reduced urine output had statistically significant association with elevated PCR. Occurrence of eclampsia, abruptio placenta, HELLP syndrome, PPH, DIC, maternal ICU admission, preterm delivery, delivery by LSCS and NICU admission had significant association with increased PCR.

\section{CONCLUSIONS}

Spot urinary protein / creatinine ratio measured in the second trimester of pregnancy can predict the subsequent development of pre-eclampsia.

\section{KEY WORDS}

Urinary Spot Protein Creatinine Ratio, Pre-Eclampsia
Corresponding Author: Dr. Sheila Kamalasan Pillai, Department of Obstetrics \& Gynaecology, Sriher, Chennai, \# 32, Defence Officers Colony, Ekkattuthangal, Chennai, Tamil Nadu, India.

E-mail: drsheilasunil@gmail.com

DOI: $10.14260 / j e m d s / 2020 / 752$

How to Cite This Article:

Jayaraman P, Pillai SK. Prediction of preeclampsia in second trimester by estimating the spot urinary protein creatinine ratio. $J$ Evolution Med Dent Sci 2020;9(46):34273433, DOI: $10.14260 /$ jemds/2020/752

Submission 02-08-2020,

Peer Review 01-10-2020,

Acceptance 08-10-2020,

Published 16-11-2020.

Copyright (c) 2020 Priyanka Jayaraman et al. This is an open access article distributed under Creative Commons Attribution License [Attribution 4.0 International (CC BY 4.0)] 


\section{BACKGROUND}

Hypertensive Disorders of Pregnancy (HDP) are unique to pregnancy, affecting $5 \%$ to $8 \%$ of all pregnant women. ${ }^{1}$ It can occur anytime in pregnancy or delivery and even in the postpartum period. In spite of the improvement in maternal and neonatal care, hypertensive disorders of pregnancy are major causes of maternal and perinatal morbidity and mortality in both developed and developing countries. Normal physiological adaptations of pregnancy are impaired or absent in hypertensive disorders of pregnancy. It is essentially a consequence of immunological intolerance between the maternal and fetal tissue.

Preeclampsia is a multisystem disorder characterized by endothelial dysfunction. The cause of preeclampsia is still unknown even though many theories have been proposed. The pathophysiology is quite complex and heterogenous. The various pathophysiological mechanisms include impaired vascular remodelling at the maternal-fetal interface, exaggerated immunological response to paternal antigens and placental dysfunction or endothelial damage. Often these factors will be influenced by genetic and environmental factors. But the essential feature in all women with preeclampsia is 'global vasospasm' ${ }^{2}$

Studies have shown that the clinical manifestations of hypertensive disorders of pregnancy start after 20 weeks of gestation. But the actual pathophysiology starts much earlier. If the disease is identified at this early stage, it could be prevented to some extent. Since the time research has been shifted towards prediction of pre-eclampsia there are numerous clinical, biochemical, functional and radiological markers that have been proposed to predict preeclampsia. These are markers of placental dysfunction, endothelial dysfunction, coagulation activation, renal involvement and markers of systemic inflammation. However, the results of various studies evaluating the reliability of these markers in predicting preeclampsia have been inconsistent and many of these markers suffer from poor sensitivity and poor positive predictive value. ${ }^{3}$ Currently, there are no screening tests for preeclampsia that are reliable, valid and economical.

Pre-eclampsia is specific to pregnancy and is characterized by multisystem involvement with glomerular endotheliosis. There is increased glomerular basement membrane permeability to proteins leading to significant proteinuria. Renal dysfunction leading to proteinuria, which is the diagnostic hallmark of preeclampsia, along with hyperuricemia have been used to predict adverse pregnancy outcomes. 24-hour urine protein estimation has been considered the gold standard for testing proteinuria but has the disadvantage of consuming time, delaying diagnosis, and thus delaying initiation of appropriate management. Alternative testing methods like Protein Creatinine Ratio (PCR) on a single random urine sample have correlated well with the gold standard.

Since delivery is the only cure for this disease, the pathogenic focus for all clinical manifestations has been shifted to the placenta 4 . Because of the unpredictable course of the disease and its poor prognosis especially in the presence of complications, treatment has to be initiated promptly on the basis of the symptoms and signs that appear in the affected women. The termination of pregnancy will reduce the complications and also the further progression of the disease.
Therefore, this study is being done to estimate the spot urinary protein creatinine ratio in pregnant women from 13 to 20 weeks of gestation and to predict their risk of developing hypertensive disorders of pregnancy subsequently. The quick and early prediction of this disease will go a long way in preventing the severe morbidity or even mortality that can happen during the course of this disease.

\section{METHODS}

After obtaining clearance from Institutional Ethical Committee this study was conducted as a prospective observational study in the Department of Obstetrics and Gynaecology at Sri Ramachandra Medical College and Research Institute, Chennai during the period from November 2017 to October 2019 to assess whether spot urinary protein creatinine ratio measured in second trimester of pregnancy can predict the subsequent development of preeclampsia.

\section{Inclusion Criteria}

- Antenatal women with singleton live fetus with gestational age between 13 and 20 weeks by LMP (Last Menstrual Period) and confirmed by ultrasound.

\section{Exclusion Criteria}

- Multi fetal pregnancy.

- Pregnant women with haematuria, dipstick positive proteinuria, urinary tract infection, acute renal failure and chronic kidney diseases.

\section{Sample Size}

Based on the literature, considering the proportion of cases with elevated PCR as $5 \%$, with absolute precision of $2 \%$ and $95 \%$ confidence interval, the sample size was calculated as 457. By adding $10 \%$ for being lost to follow up the sample size was decided as 502. During the study period, 24 participants were lost to follow up and hence 478 participants were included for analysis.

\section{Data Collection}

After taking the patient's written informed consent, using a proforma a detailed history and was collected and clinical examination was conducted for all the study participants. From all the study participants, midstream urine samples were collected and analysed for urinary protein creatinine ratio during 13 - 20 weeks of gestation. Urine protein was measured by immunoturbidometric method using commercially available kit (Beckman Coulter Kit) and urine creatinine was measured by modified kinetic Jaffe reaction without depolarization.

All the patients were followed up till delivery and in the early postpartum period for the development of pre-eclampsia and any maternal complications. After delivery new-born babies were followed up till early neonatal period for adverse neonatal outcomes. 


\section{Data Analysis}

Only the observations from the patients who have been completely followed up till delivery were taken up for statistical analysis. The data was entered in excel sheet and analysed using SPSS (Version 17). Descriptive statistics with mean, standard deviation and proportions (\%) were calculated for quantitative variables. To test the hypothesis chi square test and independent sample t test was used. P value < 0.05 was considered as statistically significant.

\section{RESULTS}

In this study a total of 500 antenatal cases were included at the initiation of the study but 22 patients were lost to follow up during the study period. Thus, finally a total of 478 cases were included in the analysis.

In this study there were 29 patients (6.1\%) with PCR more than 0.3 and 449 patients (93.9\%) with PCR less than 0.3. (Table 1)

\begin{tabular}{|ccc|}
\hline Protein Creatinine Ratio & Frequency & Percentage \\
$<0.3$ & 449 & 93.9 \\
$\geq 0.3$ & 29 & 6.1 \\
Total & $\mathbf{4 7 8}$ & $\mathbf{1 0 0}$ \\
\hline Table 1. Percentage of Cases with Elevated Protein Creatinine Ratio \\
\hline
\end{tabular}

Among the 478 study participants, $19.5 \%$ of study participants belonged to age group of less than or equal to 25 years, $59 \%$ of the study participants belonged to age group of 26 - 30 years and $21.5 \%$ of the study participants belonged to the age group 3 - 35 years of age. On assessing the association between the PCR and age group, it was found that there was no statistically significant association between both variables ( $p=0.135$ ). In this study majority of the study participants (61.1\%) were primigravidae and $38.9 \%$ were multi gravidae. Among the 29 cases with PCR $\geq 0.3,69 \%$ and $31 \%$ were primi and multi gravidae respectively. The association between the parity and PCR levels was not statistically significant ( $p=$ 0.369).

Majority of the study participants (36.2\%) entered the study during 14.1 - 16 weeks of gestation. $33.5 \%, 24.7 \%$ and $5.6 \%$ of participants entered the study during the gestational period of 16.1 - 18 weeks, 18.1 - 19.6 weeks and 13 - 14 weeks, respectively. There was no statistically significant association found between gestational age at entry into the study and PCR. ( $p=0.217$ ) Mean gestational age among cases with PCR $\geq 0.3$ was found to be $16.4 \pm 1.93$ weeks and among cases with PCR $<0.3$ was $16.55 \pm 1.77$ weeks. There was no statistical difference between the two groups with respect to gestational age at entry into the study. $(\mathrm{p}=0.667)$

Mean Systolic Blood Pressure (SBP) among cases with PCR $\geq 0.3$ was found to be $147.24 \pm 14.12 \mathrm{mmHg}$. Among cases with PCR $<0.3$ it was $124.92 \pm 8.64 \mathrm{mmHg}$. A statistically significant difference was noted between the two groups with respect to systolic blood pressure $(p=0.000)$. Mean Diastolic Blood Pressure (DBP) among cases with PCR $\geq 0.3$ was found to be $95.52 \pm 11.52 \mathrm{mmHg}$. Mean diastolic pressure among cases with PCR $<0.3$ was $76.57 \pm 6.36 \mathrm{mmHg}$. Also, there was statistically significant difference noted between the two groups with respect to diastolic blood pressure $(p=0.000)$.

Among the 478 antenatal cases included in the study, during the follow up period 27 cases (5.6\%) developed preeclampsia. All these cases were found to have PCR $\geq 0.3$. Among the 29 cases with PCR $\geq 0.3,93.1 \%$ (27 cases) developed preeclampsia. On assessing the association between the development of preeclampsia and PCR, statistically significant association was found between development of preeclampsia and PCR $(p=0.000)$. (Table 2)

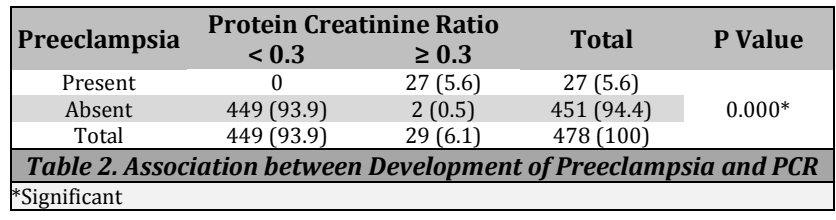

In this study, among the 27 cases with preeclampsia 21 cases $(77.8 \%)$ had mild preeclampsia and 6 cases (22.2\%) had severe preeclampsia.

Mean PCR among cases with preeclampsia was found to be $1.1 \pm 0.93$ and among cases without preeclampsia was $0.17 \pm$ 0.11 . There was a statistically significant difference noted between those with and without preeclampsia with respect to PCR value $(p=0.000)$. (Table 3$)$

\begin{tabular}{|c|c|c|c|}
\hline \multirow{2}{*}{ Preeclampsia } & \multicolumn{2}{|c|}{ Protein Creatinine Ratio } & \multirow{2}{*}{ P Value } \\
\hline & Mean & Std. Deviation & \\
\hline Present & 1.1 & 0.93 & \multirow{2}{*}{$0.000^{*}$} \\
\hline Absent & 0.17 & 0.11 & \\
\hline \multirow{2}{*}{\multicolumn{4}{|c|}{$\begin{array}{l}\text { Table 3. Difference in Mean PCR with Respect to Preeclampsia } \\
\text { Significant }\end{array}$}} \\
\hline Significant & & & \\
\hline
\end{tabular}

Among the 478 antenatal cases included in the study during the follow up period. 1 case $(0.2 \%)$ developed eclampsia and she had PCR $\geq 0.3$. Among the 29 cases with PCR $\geq 0.3,3.4 \%$ ( 1 case) developed eclampsia. On evaluating the association between occurrence of eclampsia and elevated PCR, there was statistically significant association found between occurrence of eclampsia and PCR ( $p=0.000)$.

In this study 24 patients (5\%) had headache. The remaining $95 \%$ did not have complaints of headache during the study period. Among the 24 cases with headache, 13 (2.7 $\%)$ had PCR $\geq 0.3$ and 11 cases (2.3\%) had PCR $<0.3$. Among the 29 cases with PCR $\geq 0.3,44.8 \%$ (13 cases) had headache. On assessing the association between headache and elevated PCR there was a statistically significant association found $(\mathrm{p}=$ 0.000 )

In this study 4 cases ( $0.8 \%)$ had blurring of vision and all the cases belonged to PCR $\geq 0.3$ group. Among the 29 cases with PCR $\geq 0.3,13.8 \%$ (4 cases) had blurring of vision. On assessing the association between blurring of vision and elevated PCR there was a statistically significant association found $(\mathrm{p}=0.000)$.

In this study 5 cases ( $1 \%$ ) had epigastric pain and among them $3(0.6 \%)$ belonged to PCR $\geq 0.3$ and $2(0.4 \%)$ had PCR < 0.3 group. Among the 29 cases with PCR $\geq 0.3,10.3 \%$ ( 3 cases) had epigastric pain. On assessing the association between epigastric pain and elevated PCR there was no statistically significant association found $(\mathrm{p}=0.094)$.

In this study 9 cases (1.9\%) gave history of reduced urine output. Among them 8 cases (1.7\%) belonged to PCR $\geq 0.3$ and 1 case $(0.2 \%)$ had PCR $<0.3$ group. Among the 29 cases with $\mathrm{PCR} \geq 0.3,27.6 \%$ (8 cases) had reduced urine output. On assessing the association between history of reduced urine output and elevated PCR there was a statistically significant association found $(\mathrm{p}=0.000)$. 
In this study 10 cases (2.1\%) had PPH and among them 8 cases (1.7\%) had PCR $\geq 0.3$ and 2 cases $(0.4 \%)$ had PCR $<0.3$. Among the 29 cases with PCR $\geq 0.3,27.6 \%$ (8 cases) had PPH. On assessing the association between PPH and elevated PCR there was statistically significant association found $(\mathrm{p}=$ 0.000).

In this study 9 cases (1.9\%) had abruptio placenta and among them 8 cases $(1.7 \%)$ had PCR $\geq 0.3$ and 1 case $(0.2 \%)$ had PCR $<0.3$. Among the 29 cases with PCR $\geq 0.3,27.6 \%$ (8 cases) had abruptio placenta. On assessing the association between abruptio placenta and elevated PCR there was statistically significant association found $(p=0.000)$.

In this study 2 cases $(0.4 \%)$ had HELLP syndrome and among them 1 case $(0.2 \%)$ had PCR $\geq 0.3$ and 1 case had PCR $<0.3$ group. Among cases with PCR $\geq 0.3,3.4 \%$ ( 1 case) had HELLP syndrome. On assessing the association between HELLP syndrome and elevated PCR there was statistically significant association found ( $\mathrm{p}=0.009)$.

Among the 478 antenatal cases included in the study 1 case $(0.2 \%)$ had DIC and she had PCR $\geq 0.3$. Among cases with PCR $\geq 0.3,3.4 \%$ (1 case) had DIC. On assessing the association between DIC and PCR, there was statistically significant association found between DIC and elevated PCR ( $p=0.000)$.

In this study 49 cases $(10.3 \%)$ had preterm delivery. Among them 16 cases ( $3.3 \%$ ) had PCR $\geq 0.3$ and 33 cases (6.9 $\%)$ had PCR $<0.3$. Among the 29 cases with PCR $\geq 0.3,55.2 \%$ (16 cases) and $44.8 \%$ (13 cases) had preterm and term, respectively. On assessing the association between gestational age at delivery and PCR there was statistically significant association found $(\mathrm{p}=0.000)$. (Table 4 )

\begin{tabular}{|c|c|c|c|c|}
\hline \multirow{2}{*}{$\begin{array}{c}\text { Gestational Age } \\
\text { at Delivery }\end{array}$} & \multicolumn{2}{|c|}{ Protein Creatinine Ratio } & \multirow{2}{*}{ Total } & \multirow{2}{*}{ P Value } \\
\hline & $<0.3$ & $\geq 0.3$ & & \\
\hline Preterm & $33(6.9)$ & $16(3.3)$ & $49(10.3)$ & \multirow{3}{*}{$0.000^{*}$} \\
\hline Term & $416(87)$ & $13(2.7)$ & 429 (89.7) & \\
\hline Total & $449(93.9)$ & $29(6.1)$ & $478(100)$ & \\
\hline ble 4.Ass & tion betwee & tational & t Delivery & $\overline{d P C R}$ \\
\hline
\end{tabular}

Among the 49 cases who had preterm delivery, 33 cases (67.3\%) delivered during 34.1 - 37 weeks of gestation. 15 cases (30.6\%) delivered during 28.1 - 34 weeks of gestation. 1 case (2\%) delivered before 28 weeks of gestation. Among cases with PCR $\geq 0.3,3.4 \%$ ( 1 case), $17.2 \%$ (5 cases) and 34.5 $\%$ (10 cases) had gestational age of $\leq 28$ weeks, 28.1 - 34 weeks and 34.1 - 37 weeks, respectively at delivery. On assessing the association between the gestational age of preterm delivery and PCR there was no statistically significant association found $(\mathrm{p}=0.341)$.

Mean gestational age at delivery among cases with PCR $\geq$ 0.3 was found to be $36.48+/-1.59$ weeks. Mean gestational age at delivery among cases with PCR $<0.3$ was found to be $38.45+/-1.34$ weeks. There was statistically significant difference between the two groups with respect to the mean gestational age at delivery. $(\mathrm{p}=0.000)$

In this study 3 women $(0.6 \%)$ had ICU admission and among them 2 women $(0.4 \%)$ had PCR $\geq 0.3$ and 1 woman $(0.2$ $\%)$ had PCR $<0.3$. Among the 29 women with PCR $\geq 0.3,6.9 \%$ ( 2 cases) had ICU admission. On assessing the association between ICU admission and PCR statistically significant association was found $(\mathrm{p}=0.000)$.

In this study 101 women (21.1\%) had LSCS and the remaining 377 women (78.9\%) delivered by spontaneous vaginal delivery with episiotomy. Among the 29 women with
PCR $\geq 0.3,20$ cases (68.96\%) delivered by LSCS and 9 cases (31.06 \%) had spontaneous vaginal delivery with episiotomy. On assessing the association between mode of delivery and PCR there was statistically significant association found $(\mathrm{p}=$ 0.000) (Table 5)

\begin{tabular}{|c|c|c|c|}
\hline Mode of Delivery & $\begin{array}{l}\text { Protein Creatinine Ratio } \\
<0.3 \quad \geq 0.3\end{array}$ & Total & P Value \\
\hline LSCS & $81(16.9) \quad 20(4.2)$ & $101(21.1)$ & \\
\hline SVD with episiotomy & $368(77)$ & 377 (78.9) & $0.000^{*}$ \\
\hline Total & 449 (93.9) & $478(100)$ & \\
\hline \multicolumn{4}{|c|}{ Table 5. Association between Mode of Delivery and PCR } \\
\hline
\end{tabular}

In this study 209 of the new-borns ( $43.7 \%$ ) were male and $269(56.3 \%)$ of the new-born were females, respectively. Among the cases with PCR $\geq 0.3,41.4 \%$ (12 cases) had male babies and $58.6 \%$ (17 cases) had female babies. On assessing the association between gender of new-born and PCR there was no statistically significant association found $(p=0.793)$.

In this study 18 (3.8\%) of the new-borns had complications and among them $10(2.1 \%)$ had mothers with PCR $<0.3$ and 8 (1.7\%) had mothers with PCR $\geq 0.3$. On assessing the association between new-born complications and PCR there was statistically significant association found $(\mathrm{p}$ $=0.000$ ). Among the 29 mothers with PCR $\geq 0.3,27.58 \%$ (8 cases) had babies with complications. There were four cases of prematurity, two cases of HIE (Hypoxic Ischemic Encephalopathy) and 2 cases needed ventilatory support. Similarly, among the cases with PCR $<0.3$, there were six cases with prematurity. Three cases needed ventilatory support and there was one case with HIE. There were no cases of necrotizing enterocolitis or electrolyte imbalance reported among both the groups. Also, no mortality was reported in both the groups.

In this study 26 cases (5.4\%) had NICU (Neonatal Intensive Care Unit) admission and among them 6 cases $(1.3$ \%) had mothers with PCR $\geq 0.3$ and 2 cases (4.2\%) had mothers with PCR $<0.3$. Among the 29 babies with mothers having PCR $\geq 0.3,20.7 \%$ ( 6 cases) needed NICU admission. On assessing the association between NICU admission and maternal PCR there was statistically significant association found $(\mathrm{p}=0.0001)$.

\section{DISCUSSION}

Preeclampsia is a multisystem disorder with endothelial dysfunction which affects 3 - 5\% of all pregnancies and contributes greatly to fetomaternal morbidity and mortality. Renal dysfunction leading to proteinuria (a diagnostic hallmark of preeclampsia), along with hyperuricemia have been used to predict adverse pregnancy outcomes. 24-hour urine protein estimation has been considered the gold standard for testing proteinuria but has the disadvantage of consuming time, delaying diagnosis, and thus delaying initiation of appropriate management. Alternative testing methods like PCR on a single random urine sample have correlated well with the gold standard. In this study $6.1 \%$ of patients (29 cases) had PCR more than or equal to 0.3 and 93.9 $\%$ (449 cases) had PCR less than 0.3. Statistically significant difference was noted between those with PCR greater than or equal to 0.3 and those with PCR $<0.3$ with respect to their 
mean systolic and diastolic blood pressures. Also, participants with elevated blood pressure were predominantly found to have spot PCR more than 0.3, when compared to the participants with normal blood pressure (normotensive) which was found to be statistically significant. ( $\mathrm{P}$ value $=$ 0.000) Among the patients with increased spot PCR ( 29 cases), 27 cases developed pre-eclampsia. $6(22.2 \%)$ cases had severe preeclampsia and 21 (77.8\%) cases had mild preeclampsia. Among the pre-eclampsia cases, one developed eclampsia. There was a statistically significant association between occurrence of eclampsia and increased spot PCR. Mean PCR among cases with preeclampsia was found to be $1.1 \pm 0.93$ and among cases without preeclampsia was $0.17 \pm 0.11$. There was a statistically significant difference noted between those with and without preeclampsia with respect to PCR value ( $\mathrm{p}=$ 0.000).On assessing the association between PCR levels and imminent symptoms, history of headache, blurring of vision and reduced urine output had statistically significant association with elevated PCR. No statistically significant association was found between elevated PCR and epigastric pain. Also, the occurrence of abruptio placenta, HELLP syndrome, DIC and PPH had statistically significant association with increased PCR. In our study among the 29 cases with PCR $\geq 0.3,55.2 \%$ (16 cases) had preterm delivery. There was statistically significant association found between gestational age at delivery and elevated PCR.

Mean gestational age at delivery among cases with PCR $\geq$ 0.3 was found to be $36.48+/-1.59$ weeks. Mean gestational age at delivery among cases with PCR $<0.3$ was found to be $38.45+/-1.34$ weeks. There was statistically significant difference between the two groups with respect to the mean gestational age at delivery. $(\mathrm{p}=0.000)$. In our study among the cases with PCR $\geq 0.3,20$ cases ( $68.96 \%$ ) delivered by LSCS and 9 cases $(31.06 \%)$ had spontaneous vaginal delivery with episiotomy. On assessing the association between mode of delivery and PCR there was statistically significant association found $(p=0.000)$ between delivery by LSCS and elevated PCR. Maternal ICU admission also had statistically significant association with increased PCR. Similarly, NICU admission and complications in new-born were the new-born factors found to be significantly associated with increased PCR.

The gold standard for measuring proteinuria is 24-hour urine protein estimation. ${ }^{3}$ unfortunately the 24-hour urine collection takes an entire day to collect and is therefore not available to guide clinical decisions upon first evaluation. A rapid screening test to predict 24-hour proteinuria in combination with other presenting signs and symptoms can help a clinician determine the appropriate amount of surveillance and guide care during the initial 24-hour period. Traditionally dipstick urinalysis has been used as this screening test. ${ }^{4}$ The dipstick analysis using visual reagent strips is quick, portable and easy to do. However, urine samples are taken at varying times of the day. This test is complicated by relatively high false positive and false negative rates. ${ }^{5-6}$ The dipstick urinalysis measures the concentration of protein in urine and is susceptible to fluctuations in the water content of urine. Dilute urine may underestimate the amount of protein that would be collected in a 24-hour urine collection whereas concentrated urine may overestimate it. In the presence of stable glomerular filtration rate, urinary creatinine is excreted at a fairly constant rate. ${ }^{7}$ International Society for Study of Hypertension in Pregnancy (ISSHP) has accepted spot PCR as a method of identification of significant proteinuria ( $\geq 300 \mathrm{mg} / 24$ hours). ${ }^{8}$

BK Dwyer et $\mathrm{al}^{9}$ conducted a study by comparing urine protein creatinine ratio with urinalysis to predict significant proteinuria. The study was conducted on 116 pregnant mothers. The study revealed urine PCR is $66 \%$ sensitive but urinalysis is $41 \%$ sensitive concluding that urine PCR is a better screening test.

Luis Sanchez-Ramos et al ${ }^{10}$ conducted a meta-analysis to investigate accuracy of protein creatinine ratio, twenty-four trials with 3186 aggregate participants met inclusion criteria. Pooled sensitivities and pooled specificity were $91 \%$ and 86.3 $\%$.

Eleni G Elia, Amy 0 Robb et al ${ }^{11}$ in their study they concluded that ACR (Albumin Creatinine Ratio) is an independent prognostic factor for maternal and neonatal adverse outcomes in suspected pre-eclampsia. ACR may be useful to inform risk predictions within a prognostic model.

Christopher P Price et al ${ }^{12}$ conducted a systematic review and reported Sensitivities and specificities for tests ranged between $69 \%$ and $96 \%$ and $41 \%$ and $97 \%$ respectively.

Shahrzad Zadehmodarrees et $\mathrm{al}^{13}$ conducted a study and reported that all women with suspected pre-eclampsia had significant proteinuria. The single voided $\mathrm{P} / \mathrm{C}$ ratio demonstrated a sensitivity of $94 \%$ and specificity of $96 \%$ at the cut off $\geq 0.2 \mathrm{mg} / \mathrm{mg}$.

Wheeler et al ${ }^{14}$ conducted a study among 126 patients admitted for evaluation of preeclampsia and reported a strong correlation of random spot urine $\mathrm{P} / \mathrm{C}$ ratio with 24-h urine protein levels (Pearson's $r=0.88$ ). The optimal $\mathrm{P} / \mathrm{C}$ cut off was 0.21 and 3.0. AUC was 0.86 for cut-off values of 0.21 and 1.0 for cut-off values of 3.0. All of them showed excellent accuracy. They concluded that though there is a strong association between the spot urine $\mathrm{P} / \mathrm{C}$ ratio and 24-h urine protein excretion, the former lacks the ability to measure proteinuria quantitatively.

Other reports have given conflicting results and report that 24-h urine collection should remain the standard for evaluation of preeclampsia. Durnwald and Merceret $\mathrm{al}^{15}$ in their comparative study between 24 -h urine protein and spot urine $\mathrm{P} / \mathrm{C}$ ratio among 220 preeclamptic women had a mean age of 26.1 years and gestational age of 36.5 weeks. They reported a poor correlation coefficient of 0.41 between $24-\mathrm{h}$ urine and spot urine P / C ratio. The ROC analysis revealed no clear shoulder although the AUC was 0.8 with a sensitivity of $55.8 \%$ and specificity of $81 \%$ at a cut-off value of 0.3 for spot urine $\mathrm{P} / \mathrm{C}$ ratio. Morris et $\mathrm{al}^{16}$ in their systematic review and meta-analysis concluded that on an average, across all studies the optimal threshold of spot $\mathrm{P} / \mathrm{C}$ ratio to detect significant proteinuria is between 0.30 and 0.35 , relating to sensitivity and specificity values above $75 \%$.

Newman et al ${ }^{17}$ concluded in their study that women with preeclampsia and massive proteinuria did not have increased maternal morbidity compared with women with severe or mild proteinuria.

Gai et al ${ }^{18}$ proposed that the random urine $\mathrm{P} / \mathrm{C}$ ratio could replace the urinary dipstick test, as they found that the highest regression coefficient was between 24-hour urine protein and random urine $\mathrm{P} / \mathrm{C}$ ratio $(\mathrm{r}=0.72)$, and the lowest between random urine $\mathrm{P} / \mathrm{C}$ ratio and the urinary dipstick test $(\mathrm{r}=0.72)$ in patients with renal disease. They also revealed that the urinary dipstick test failed to detect a pathological proteinuria 
in $31.6 \%$ of their study population while random urine P / C ratio failed to detect in only $5.4 \%$. Meanwhile, in their study with preeclamptic pregnancy, Eigbefoh et al ${ }^{19}$ showed that a random urine $\mathrm{P} / \mathrm{C}$ ratio had the highest sensitivity, $92 \%$, while the urinary dipstick test had a sensitivity of $81 \%$. Their results also showed that the urinary dipstick test had the highest false negative rate $(19 \%)$, while that of the random urine $\mathrm{P} / \mathrm{C}$ ratio was $8 \%$. Furthermore, the specificity for random urine $\mathrm{P} / \mathrm{C}$ ratio was $86 \%$, while that for the urinary dipstick test was $47 \%$. Also, in their study, the false positive rate was highest with the urinary dipstick test (53\%), and only $14 \%$ for random urine P / C ratios.

Several studies have already established the usefulness of the random urine $\mathrm{P} / \mathrm{C}$ ratio, including some that have presented evidence of good correlation with acceptable sensitivity in predicting significant proteinuria based on urine collected at different time periods. ${ }^{20-22}$ Furthermore, some reports indicate maternal age, gestational age, parity and maternal body size are not confounding factors with regard to random urine $\mathrm{P} / \mathrm{C}$ ratio. ${ }^{23}$

A good correlation between the spot urine $\mathrm{P} / \mathrm{C}$ ratio and 24-hour protein excretion has been demonstrated in patients with diabetic nephropathy, lupus nephritis, chronic kidney disease, and transplanted kidneys. ${ }^{24}$ The National Kidney Foundation guidelines have suggested that spot urine samples should be used to detect and monitor proteinuria in children and adults. ${ }^{25}$

A retrospective study by Schiff et $\mathrm{al}^{26}$ demonstrated that no differences in maternal or fetal outcomes were found between pregnancies with marked increases in proteinuria and those with modest or no increases. Newman et $\mathrm{al}^{27}$ sought to determine whether delayed delivery of pre-eclampsia with massive proteinuria increased maternal or neonatal morbidity. They retrospectively reviewed parturients admitted with pre-eclampsia at $\geq 37$ weeks of gestation, divided into three groups of proteinuria (mild, severe or massive) and compared the outcomes.

Sampling random urine for a protein / creatinine ratio is based on the assumption that urinary protein and creatinine excretion in the presence of a stable glomerular filtration rate during the day remains constant. ${ }^{28}$ Protein excretion rates, however, can vary hour to hour in preeclampsia due to renal vasoconstriction. ${ }^{29}$ Chesley reported up to a 5 -fold variation of protein excretion in four hourly collections. In most previous studies, a significant correlation between the protein / creatinine ratio or albumin / creatinine ratio with 24-hour urine were reported in women with hypertensive disease of pregnancy. ${ }^{30-32}$ However, a high correlation does not necessarily support the fact that the ratio varies within a narrow range across the day. The albumin / creatinine ratio might be a better estimate of renal function at that moment than 24-hour collection. However, if it is necessary to know the total amount of the albumin excreted, a 24-hour urine sample must be collected.

\section{CONCLUSIONS}

In this study, all participants who developed pre-eclampsia were found to have spot PCR of more than 0.3. Among the imminent symptoms headache, blurring of vision and reduced urine output had statistically significant association with elevated PCR. Occurrence of eclampsia, abruptio placenta, HELLP syndrome, PPH, DIC, maternal ICU admission, preterm delivery and delivery by LSCS were the maternal factors associated with increased PCR. Similarly, NICU admission and complications in newborn were the newborn factors found to be associated with increased PCR. It is concluded that spot urinary protein / creatinine ratio measured in the second trimester of pregnancy can predict the subsequent development of pre-eclampsia.

Data sharing statement provided by the authors is available with the full text of this article at jemds.com.

Financial or other competing interests: None.

Disclosure forms provided by the authors are available with the full text of this article at jemds.com.

\section{REFERENCES}

[1] Report of the national high blood pressure education program working group report on high blood pressure in pregnancy. Am J Obstet Gynaecol 2000;183(1):S1-22.

[2] Hennessy A, Makris A. Preeclamptic nephropathy. Nephrology (Carlton) 2011;16:134-43.

[3] Price CP, Newall RG, Boyd JC. Use of protein: creatinine ratio measurements on random urine samples for prediction of significant proteinuria:a systematic review. Clin Chem 2005;51(9):1577-86.

[4] Meyer NL, Mercer BM, Friedman SA, et al. Urinary dipstick protein: a poor predictor of absent or severe proteinuria. Am J Obstet Gynecol 1994;170(1 Pt 1):137-41.

[5] Kuo VS, Koumanantakis G, Gallery EDM. Proteinuria and its assessment in normal and hypertensive pregnancy. Am J Obst Gynecol 1992;167(3):723-8.

[6] Waugh JJS, Bell SC, Kilby MD, et al. Optimal bedside analysis for the detection of proteinuria in hypertensive pregnancy: a study of diagnostic accuracy. Br J Obstet Gynaecol 2005;112(4):412-7.

[7] Vestergaard P, Leverett R. Constancy of urinary creatinine excretion. J Lab Clin Med 1958;51(2):211-8.

[8] Brown MA, Lindheimer MD, de Swiet M, et al. The classification and diagnosis of the hypertensive disorders of pregnancy: statement from the International Society for the Study of Hypertension in Pregnancy (ISSHP). Hypertens Pregnancy 2001;20(1):9-14.

[9] Dwyer BK, Gorman M, Carroll IR, et al. Urinalysis vs urine protein-creatinine ratio to predict significant proteinuria in pregnancy. J Perinatol 2008;28(7);461-7.

[10] Sanchez-Ramos L, Gillen G, Zamora J, et al. The protein to creatinine ratio for prediction of significant proteinuria in patients at risk for pre eclampsia:a meta analysis. Ann Clin Lab Sci 2013;43(2);211-20.

[11] Elia EG, Robb AO, Hemming K, et al. Is the first urinary albumin/creatinine ratio (ACR) in women with suspected preeclampsia a prognostic factor for maternal and neonatal adverse outcome? A retrospective cohort study. Acta Obstet Gynecol Scand 2017;96(5):580-8.

[12] Price CP, Newall RG, Boyd JC. Use of protein:creatinine ratio measurements on random urine samples for prediction of significant proteinuria: a systematic review. Clin Chem 2005;51(9):1577-86. 
[13] Zadehmodarres S, Razzaghi MR, Habibi G, et al. Random urine protein to creatinine ratio as a diagnostic method of significant proteinuria in pre- eclampsia. Aust N Z J Obstet Gynecol 2006;46(6):501-4.

[14] Wheeler TL, Blackhurst DW, Dellinger EH, et al. Usage of spot urine protein to creatinine ratios in the evaluation of preeclampsia. Am J Obstet Gynecol 2007;196(5):465.e14.

[15] Durnwald C, Mercer B. A prospective comparison of total protein/creatinine ratio versus 24 -hour urine protein in women with suspected preeclampsia. Am J Obstet Gynecol 2003;189(3):848-52.

[16] Morris RK, Riley RD, Doug M, et al. Diagnostic accuracy of spot urinary protein and albumin to creatinine ratios for detection of significant proteinuria or adverse pregnancy outcome in patients with suspected pre-eclampsia: systematic review and meta-analysis. BMJ 2012;345:e4342.

[17] Newman MG, Robichaux AG, Stedman CM, et al. Perinatal outcomes in preeclampsia that is complicated by massive proteinuria. Am J Obstet Gynecol 2003;188(1):264-8.

[18] Gai M, Motta D, Giunti S, et al. Comparison between 24-h proteinuria, urinary protein/creatinine ratio and dipstick test in patients with nephropathy: patterns of proteinuria in dipstick-negative patients. Scand J Clin Lab Invest 2006;66(4):299-307.

[19] Eigbefoh JO, Abebe J, Odike MA, et al. Protein/creatinine ratio in random urine specimens for quantitation of proteinuria in pre-eclampsia. The Internet Journal of Gynecology and Obstetrics 2006;8(1).

[20] Silpraset S, Phaloprakarn C, Manusirivithaya S, et al. A sixhour urinary protein-creatinine ratio for predicting significant proteinuria in preeclampsia. Thai J Obstet Gynecol 2009;17(1):30-6.

[21] Saikul S, Wiriyasirivaj B, Charoenchinont P. First 4-hour urinary protein-creatinine ratio for diagnosis of significant proteinuria in preeclampsia. J Med Assoc Thai 2006;89(Suppl 4):S42-6.

[22] Wiwanitkit V. Periodic urinary protein creatinine ratio for predicting significant proteinuria in preeclampsia in different alternatives: time effectiveness analysis. Arch Gynecol Obstet 2010;281(3):571-3.

[23] Leanos-Miranda A, Marquez-Acosta J, Romero-Arauz F, et al. Protein: creatinine ratio in random urine samples is a reliable marker of increased 24-hour protein excretion in hospitalized women with hypertensive disorders of pregnancy. Clin Chem 2007;53(9):1623-8.

[24] Torng S, Rigatto C, Rush DN, et al. The urine protein to creatinine ratio $(\mathrm{P} / \mathrm{C})$ as a predictor of 24 -hour urine protein excretion in renal transplant patients. Transplantation 2001;72(8):1453-6.

[25] Keane WF, Eknoyan G. Proteinuria, albuminuria, risk, assessment, detection, elimination (PARADE): a position paper of the National Kidney Foundation. Am J Kidney Dis 1999;33(5):1004-10.

[26] Schiff E, Friedman S, Kao L, et al. The importance of urinary protein excretion during conservative management of severe preeclampsia. Am J Obstet Gynecol 1996;175(5):1313-6.

[27] Newman M, Robichaux A, Stedman C, et al. Perinatal outcomes in preeclampsia that is complicated by massive proteinuria. Am J Obstet Gynecol 2003;188(1):264-8.

[28] McGregor WG, Kuhn RW, Jaffe RB. Biologically active chorionic gonadotropin: synthesis by the human fetus. Sci 1983;220(4594):306-8.

[29] Nisula BC, Blithe DL, Akar A. Metabolic fate of human choriogonadotropin. J Steroid Biochem 1989;33(4B):7337.

[30] Fox H. Effect of hypoxia on trophoblast in organ culture: a morphologic and autoradiographic study. Am J Obstet Gynecol 1970;107(7):1058-64.

[31] Morssink LP, de Wolf BT, Kornman LH, et al. The relation between serum markers in the second trimester and placental pathology. A study on extremely small for gestational age fetuses. $\mathrm{Br} \mathrm{J}$ Obstet Gynaecol 1996;103(8):779-83.

[32] Heinonen S, Ryynanen M, Kirkinen P, et al. Velamentous umbilical cord insertion may be suspected from maternal serum alpha-fetoprotein and hCG. Br J Obstet Gynaecol 1996;103(3):209-13. 